\begin{tabular}{ccr} 
FOLIA & ENTOMOLOGICA & HUNGARICA \\
& ROVARTANI KÖZLEMÉNYEK & \\
Volume 81 & 2020 & pp. $95-104$ \\
\hline
\end{tabular}

\title{
New species and records of Ichneumonidae (Hymenoptera)
}

\author{
Zoltán VAS \\ Hungarian Natural History Museum, Department of Zoology, H-1088 Budapest, Baross utca 13, \\ Hungary.E-mail:vas.zoltan@nhmus.hu
}

\begin{abstract}
Temelucha xana sp. $\mathrm{n}$. is described from Spain. First records of Campoletis crassicornis (Tschek, 1871) from Algeria and Western Sahara, Campoletis katalinarum Vas, 2019 from Syria, Campoletis vimmeri (Gregor, 1938) from Albania, Dusona leptogaster (Holmgren, 1860) from Hungary, Meloboris collector (Thunberg, 1822) from Morocco and Rwanda, Nemeritis macrocentra (Gravenhorst, 1829) from Montenegro, Nepiesta tibialis Horstmann, 1977 from Greece, Temelucha annulata (Szépligeti, 1899) from North Macedonia, Temelucha caudata (Szépligeti, 1899) from Armenia and North Macedonia, Temelucha cylindrator Narolsky, 1987 from Greece, Temelucha decorata (Gravenhorst, 1829) from Armenia, Temelucha genalis (Szépligeti, 1899) from North Macedonia, Temelucha lucida (Szépligeti, 1899) and Temelucha minuta (Morley, 1912) from Spain, Temelucha variipes (Szépligeti, 1899) from North Macedonia, Diplazon laetatorius (Fabricius, 1781) from Western Sahara, Homotropus elegans (Gravenhorst, 1829) from Morocco and Western Sahara, Enicospilus glabratus (Say, 1835) from Martinique, and Thyreodon rufothorax Cameron, 1886 from French Guiana are reported. With one figure.
\end{abstract}

Key words - Campopleginae, Cremastinae, Diplazontinae, Ophioninae, Temelucha, species description, Palaearctic, Neotropical, Afrotropical

\section{INTRODUCTION}

Some recently revealed results of the ongoing identification process of Ichneumonidae material in the Hungarian Natural History Museum (HNHM, Budapest) are given in this paper: Temelucha xana sp. n. is described from Spain, and new distributional records are given for 19 ichneumon wasp species of the subfamilies Campopleginae, Cremastinae, Diplazontinae and Ophioninae, regarding the Palaearctic, Afrotropical and Neotropical regions. Taxonomy and nomenclature follow Yu \& Horstmann (1997) and Yu et al. (2012). Morphological terminology used in the species description follows GAULD (1991) and GAULD et al. (1997); however, in the cases of wing veins the corresponding terminology of TOWNES (1969) is also indicated. Identifications 
were based on GAULD (1988), Horstmann (1994), Kolarov (1997), GAULD \& Janzen (2004), Klopfstein (2014), Kolarov (2016), Vas (2016), Riedel (2017), VAs $(2019 a, b, c, 2020)$. The specimens were identified by the author using a Nikon SMZ645 stereoscopic microscope. Taxa are listed alphabetically, first by subfamilies then by species. The material is deposited in HNHM. Photos were taken with a 14 MP MicroQ-U3L digital camera. Post-image work was done with ToupTek ToupView v4.7 and Photoshop CS3.

\section{RESULTS}

Campopleginae

Campoletis crassicornis (Tschek, 1871)

Material examined - Algeria: Col. Voirol, 23.III.-6.IV.1928, leg. R. Meyer,

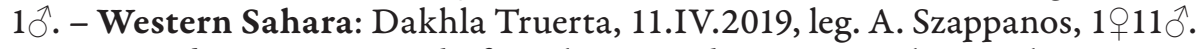

Remarks - First records for Algeria and Western Sahara. This species is widespread in the Palaearctic region (Yu et al. 2012, Riedel 2017, Vas 2019a, b).

\section{Campoletis katalinarum Vas, 2019}

Material examined - Syria: Kaifa, date unknown, leg. Reitter, 1 우.

Remarks - First record for Syria. This species was recently described from Georgia and Turkey (VAs 2019a).

\section{Campoletis vimmeri (Gregor, 1938)}

Material examined - Albania: Mt. Korab, 1800 m, 26.VII.1918, leg. E. Csiki, 1 ㅇ․

Remarks - First record for Albania. This species was known from some Western and Middle European countries (Yu et al. 2012, RIEDEL 2017).

\section{Dusona leptogaster (Holmgren, 1860)}

Material examined - Hungary: Mt. Börzsöny, Tax-rét, 47.936225, $18.933123^{\circ}, 695$ m, 22.V.2020, leg. P. G. Sulyán \& Cs. Szabóky, 1 ㅇ.

Remarks - First record for Hungary. This species is widespread in the Palaearctic region (Yu et al. 2012). 
Meloboris collector (Thunberg, 1822)

Material examined - Morocco: Agadir Oued Sous, 8.IV.2019, leg. A. Szappanos, 1 우으. - Rwanda: Kagera National Park, 1.V.1988, leg. A. Vojnits, 1 ㅇ․

Remarks - First records for Morocco and Rwanda. This species is widespread in the Palaearctic region, and in the Afrotropical region it was known from South Africa (Yu et al. 2012, VAs 2019b).

Nemeritis macrocentra (Gravenhorst, 1829)

Material examined - Montenegro: Rožaje, 4.VII.1917, leg. E. Csiki, $1 \jmath^{\Uparrow}$

Remarks - First record for Montenegro. This species is widespread in the Palaearctic region (YU et al. 2012, VAs 2020).

Nepiesta tibialis Horstmann, 1977

Material examined - Greece: Crete, Canea, 1906, leg. L. Bíró, 1 đ

Remarks - First record for Greece. This species was known from Jordan and Turkmenistan (YU et al. 2012, VAs 2019c).

\section{Cremastinae}

Temelucha annulata (Szépligeti, 1899)

Material examined - North Macedonia: prov. Skopje, Mt. Vodno, 16.VII.1997, leg. Gy. Rozner, 1 ㅇ․

Remarks - First record for North Macedonia. This species is known from several countries of the Western Palaearctic region (Yu et al. 2012).

Temelucha caudata (Szépligeti, 1899)

Material examined - North Macedonia: Dojran, Lake Dojran, 150-500 m, 9-10.V.1971, leg. J. Papp \& S. Horvatovich, 10. - Armenia: Karashamb, Aghveran, 1900 m, 2.VI.1980, leg. J. Papp, 1 ㅇ.

Remarks - First records for Armenia and North Macedonia. This species is widespread in the Palaearctic region (Yu et al. 2012). 
Temelucha cylindrator Narolsky, 1987

Material examined - Greece: Kos Island, Marimari, 25-29.IX.2003, leg. S. Mahunka, $2 \subsetneq 3 \AA$.

Remarks - First record for Greece. This species was known from Moldova and Ukraine (Yu et al. 2012).

Temelucha decorata (Gravenhorst, 1829)

Material examined - Armenia: Garni, 1200 m, 9.VII.1977, leg. L. Zombori, 19; Kuybishev, 1500m, 19.VII.1977, leg. L. Zombori, 1 .

Remarks - First records for Armenia. This species is widespread in the Palaearctic region (Yu et al. 2012).

Temelucha genalis (Szépligeti, 1899)

Material examined - North Macedonia: prov. Skopje, Mt. Vodno, 16.VII.1997, leg. Gy. Rozner, 1 ; prov. Tetovo, Zelino, 30.V.1998, leg. Gy. Rozner, $2{ }^{3}$; prov. Kavadarci, Debriste, 31.V.1998, leg. Gy. Rozner, $1{ }^{\lambda}$.

Remarks - First records for North Macedonia. This species is known from several countries of the Western Palaearctic region (Yu et al. 2012).

Temelucha lucida (Szépligeti, 1899)

Material examined - Spain: Manilva, 9.V.1984, leg. A. Podlussány, 1 ㅇ.

Remarks - First record for Spain. This species is widespread in the Palaearctic region (Yu et al. 2012).

Temelucha minuta (Morley, 1912)

Material examined - Spain: Andalusia, prov. Jaén, Puente de Génave, 27.V.2003, leg. I. \& Gy. Rozner, 1 \%.

Remarks - First record for Spain. This species is known by a relatively few records from many regions of the Old World; in the Western Palaearctic it was known from Cyprus (Yu et al. 2012). 
Temelucha variipes (Szépligeti, 1899)

Material examined - North Macedonia: Dojran, Lake Dojran, 150-500 m, 9-10.V.1971, leg. J. Papp \& S. Horvatovich, 19; prov. Prilep, Mazuciste, 31.V.1998, leg. A. Podlussány, 1 .

Remarks - First records for North Macedonia. This species is widespread in the Palaearctic region (Yu et al. 2012).

\section{Temelucha xana sp. $\mathrm{n}$.}

(Fig. 1)

Type material - Holotype: female, Spain [on label: Hispania], CastillaLa Mancha, prov. Ciudad Real, $3 \mathrm{~km} \mathrm{~S}$ of Horcajo de los Montes, 16.V.2003, leg. Ibolya \& György Rozner, specimen card-mounted, Id. No. HNHM-HYM 155047; deposited in HNHM.

Diagnosis - The new species can be distinguished from all Western Palaearctic Temelucha Förster, 1869 species by the following character states in combination: small species (body length ca $3.5 \mathrm{~mm}$ ), fore wing veins pigmented, pterostigma not unusually wide, mesosoma, except tegula, black without yellow markings, metasoma black, apical margins of tergites very narrowly, inconspicuously yellowish brown or brownish, apical margin of clypeus weakly convex, hind tibial spurs conspicuously short, longer spur slightly shorter than apical width of hind tibia, area superomedia apically closed, ovipositor sheath $2 \times$ as long as hind tibia, ovipositor straight.

Description - Female (Fig. 1). Body length ca $3.5 \mathrm{~mm}$, fore wing length ca $2.8 \mathrm{~mm}$.

Head: Antenna with 22 flagellomeres; first flagellomere long and slender, ca $3.3 \times$ as long as its apical width; preapical flagellomeres longer than wide to subquadrate. Head transverse, weakly shiny, finely granulate to finely coriaceous with dense, relatively weak punctures, and with short, greyish hairs. Ocelli small, ocular-ocellar distance $1.4 \times$ as long as ocellus diameter, posterior ocellar distance $1.8 \times$ as long as ocellus diameter. Inner eye orbits not indented, slightly divergent ventrally. Gena in dorsal view $0.55 \times$ as long as eye width, roundly narrowed behind eye. Occipital carina medially widely obsolescent, laterally and ventrally present, reaching hypostomal carina before base of mandible; hypostomal carina not elevated. Frons weakly impressed. Face almost flat in profile. Clypeus distinctly separated from face, weakly convex in profile, its apical margin weakly convex, sharp. Malar space $0.7 \times$ as long as basal width of mandible. Mandible relatively wide, upper mandibular tooth slightly longer than lower tooth. 
Mesosoma: Mesosoma with dense, short, greyish hairs, not elongated. Pronotum finely granulate to coriaceous with weak punctures, ventral half with weak wrinkles; epomia weak. Mesoscutum finely coriaceous with dense punctures, weakly shiny, convex in profile, about as long as wide; notaulus distinct, reaching middle of mesoscutum. Scuto-scutellar groove deep and wide. Scutellum finely granulate, weakly convex in profile, lateral carina only basally developed. Mesopleuron finely granulate to coriaceous with dense, relatively weak punctures, speculum almost smooth. Epicnemial carina complete, pleural part bent to anterior margin of mesopleuron reaching it slightly above its middle height. Sternaulus indistinct. Posterior transverse carina of mesosternum complete. Metanotum finely coriaceous with weak wrinkles, ca $0.5 \times$ as long as scutellum. Metapleuron finely granulate-punctate; juxtacoxal carina not developed; submetapleural carina complete. Pleural carina of propodeum strong; propodeal spiracle rather small, circular, separated from pleural carina by about $4 \times$ its length, connected to pleural carina by a distinct, long ridge. Propodeum weakly convex in profile, its apex not reaching middle length of hind coxa, finely granulate with transverse wrinkles and some weak punctures, area superomedia more finely sculptured, very finely granulate with few weak punctures and without wrinkles. Propodeal carinae well developed, area superomedia apically closed, $1.7 \times$ as long as wide, lateral sides behind costulae convergent. Fore wing with pigmented veins, without areolet; second recurrent vein $(2 m-c u)$ postfurcal; distal part of distal abscissa of $R s$ distinctly curved toward wing margin; nervulus $(\mathrm{cu}-\mathrm{a})$ interstitial, vertical; postnervulus (abscissa of $\mathrm{Cu} 1$ between $1 \mathrm{~m}-\mathrm{cu}$ and $C u 1 a+C u 1 b)$ intercepted strongly above its middle by $C u 1 a$; second discal cell ca $1.5 \times$ as long as first sub-discal cell (measured at front margins); lower external angle of second discal cell obtuse; pterostigma not unusually wide, about as wide as front width of marginal cell distal to pterostigma. Hind wing with nervellus (cu-a + abscissa of $C u 1$ between $M$ and $c u-a)$ straight, weakly reclivous, not intercepted by discoidella (distal abscissa of $C u 1$ ); discoidella spectral, proximally not connected to nervellus. Coxae very finely granulate with indistinct, weak punctures. Hind femur ca $4.5 \times$ as long as high. Hind tibial spurs conspicuously short, outer spur distinctly, inner spur slightly shorter than apical width of hind tibia. Tarsal claws small and thin, as long as or slightly longer than arolium.

Metasoma: Metasoma compressed, finely granulate to shagreened, with short, greyish hairs; second tergite with longitudinal striation characteristic of most Cremastinae. First tergite long and slender, ca $4 \times$ as long as width of its apical margin, $1.3 \times$ as long as second tergite; dorsomedian carina of first tergite weak but discernible, reaching almost to spiracle; ventral margins of first tergite almost touching each other ventrally; postpetiolus moderately bulging. Second tergite ca $1.8 \times$ as long as its apical width. Posterior margins of third and following tergites medially concave. Ovipositor sheath $2 \times$ as long as hind tibia (or as long as fore wing from base to apex of marginal cell); ovipositor straight, compressed, dorsal preapical notch weak. 


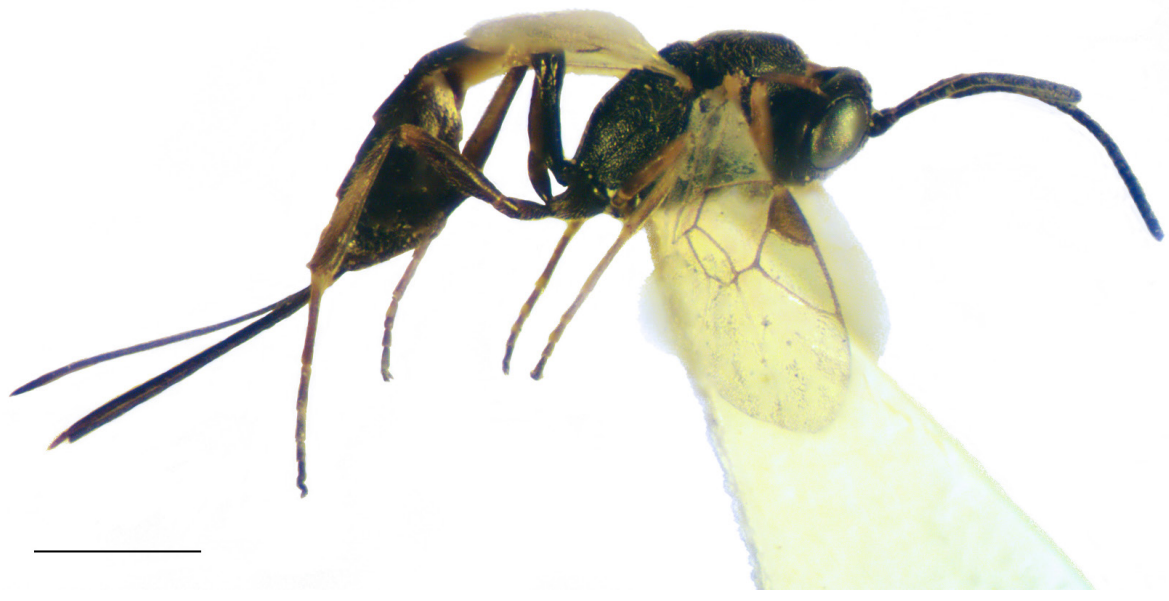

Fig. 1. Temelucha xana sp. n., holotype. Scale bar $=1 \mathrm{~mm}$ (photo by Zoltán Vas)

Colour: Antenna dark brown, scapus and pedicellus brown, apically narrowly yellowish brown. Head black, except palpi and mandible yellowish brown, mandibular teeth dark brown, clypeus and a pair of small, almost indiscernible spots at inner eye orbits on frons brownish. Mesosoma entirely black, except tegula yellowish brown. Metasoma black, apical margins of tergites very narrowly yellowish brown or brownish. Wings hyaline, wing veins and pterostigma brownish. Fore leg: coxa blackish, apically brownish; trochanter and trochantellus brown, apically narrowly yellowish; femur and tibia brownish orange. Middle leg: similar to fore leg, except femur ventrally and tibia ventrally, basally and apically more brownish. Hind leg: coxa blackish; trochanter and trochantellus blackish to dark brown, apically very narrowly yellowish brown; femur dark brown to chestnut brown, apically narrowly yellowish brown; tibia basally, ventrally and apically brown, externo-medially pale yellowish; tarsus brownish.

Male: Unknown.

Distribution - Spain.

Etymology - The specific epithet xana is derived from the Asturian noun "xana" (plural form "xanes"), meaning the mythical female creature of Spanish folklore known as xana or anjana. In some folktales xanas appear as small, thin, dark-coloured, malicious spirits, often switching their babies for those of other women, inspiring the reference to the new species, a small, thin, dark-coloured, parasitoid wasp. The specific epithet is a noun in apposition, ending not to be changed. 
Remarks on identification - By using the identification key in VAs (2016), the new species would key out with Temelucha tibialis Kolarov, 1995 at the couplet 3. T. tibialis can be easily distinguished from the new species by its distinctly convex apical margin of clypeus, parallel-sided, apically opened area superomedia, antefurcal nervulus, and extensive yellow coloration on head, mesosoma and metasoma. Due to its small size and conspicuously short hind tibial spurs T. latastigma Kolarov, 2016, a Western Palaearctic species described after the publication of VAs (2016), is also somewhat similar; this species can be readily distinguished from the new species by its conspicuously large pterostigma and extensive yellow coloration on head, mesosoma and metasoma.

\section{Diplazontinae}

Diplazon laetatorius (Fabricius, 1781)

Material examined - Western Sahara: Dakhla Truerta, 11.IV.2019, leg. A. Szappanos, 3 우.

Remarks - First record for Western Sahara. This species has a cosmopolitan distribution (Yu et al. 2012, KLOPFSTEIN 2014).

Homotropus elegans (Gravenhorst, 1829)

Material examined - Morocco: Agadir Oued Sous, 8.IV.2019, leg. A. Szappanos, 1 $\delta^{\text {. }}$ - Western Sahara: Dakhla Truerta, 11.IV.2019, leg. A. Szappanos, 3 우소.

Remarks - First records for Morocco and Western Sahara. This species is widespread in the Holarctic region (Yu et al. 2012, KLOPFSTEIN 2014).

\section{Ophioninae}

Enicospilus glabratus (Say, 1835)

Material examined - Martinique: Saint-Pierre, light trap, 3-24.VII.2018, leg. Sz. Kiss, $1{ }^{\Uparrow}$.

Remarks - First record for Martinique. This species is widely distributed in the Neotropical and Nearctic regions (YU et al. 2012). 


\section{Thyreodon rufothorax Cameron, 1886}

Material examined - French Guiana: Patawa Camp, light trap, 9-21. IX.2017, leg. Sz. Kiss, 1 ㅇ.

Remarks - First record for French Guiana. This species was known from Panama and Costa Rica (Yu et al. 2012).

Acknowledgements - Thanks are due to Ottó Merkl (HNHM) for his valuable comments on the manuscript, and to Viktória Szőke (HNHM) for post-image work and for buying and donating the Neotropical specimens for the Hymenoptera Collection of HNHM. The author was supported by the Hungarian Government, Ministry of Human Capacities (Emberi Erőforrások Minisztériuma) in the frame of the NTP-NFTÖ-19-B-0007 scholarship (Nemzet Fiatal Tehetségeiért Ösztöndij).

\section{REFERENCES}

GAULD I. D. 1988: A survey of the Ophioninae (Hymenoptera: Ichneumonidae) of tropical Mesoamerica with special reference to the fauna of Costa Rica. - Bulletin of the British Museum (Natural History), Entomology 57: 1-309.

GAULD I. D. 1991: The Ichneumonidae of Costa Rica, 1. Introduction, keys to subfamilies, and keys to the species of the lower Pimpliform subfamilies Rhyssinae, Poemeniinae, Acaenitinae and Cylloceriinae. - Memoirs of the American Entomological Institute 47: 1-589.

GAuld I. D. \& JAnzen D. H. 2004: The systematics and biology of the Costa Rican species of parasitic wasps in the Thyreodon genus-group (Hymenoptera: Ichneumonidae). - Zoological Journal of the Linnean Society 141(3): 297-351. https://doi.org/10.1111/j.1096-3642.2004.00116.x

Gauld I. D., Wahl D., Bradshaw K. Hanson P. \& Ward S. 1997: The Ichneumonidae of Costa Rica, 2. Introduction and keys to species of the smaller subfamilies, Anomaloninae, Ctenopelmatinae, Diplazontinae, Lycorininae, Phrudinae, Tryphoninae (excluding Netelia) and Xoridinae, with an appendix on the Rhyssinae. - Memoirs of the American Entomological Institute 57: 1-485.

HorstmanN K. 1994: Nachtrag zur Revision der westpaläarktischen Nemeritis-Arten (Hymenoptera, Ichneumonidae, Campopleginae). - Mitteilungen Münchener Entomologischen Gesellschaft 84: 79-90.

KlopfSTein S. 2014: Revision of the Western Palaearctic Diplazontinae (Hymenoptera, Ichneumonidae). - Zootaxa 3801: 1-143. https://doi.org/10.11646/zootaxa.3801.1.1

Kolarov J. 1997: A review of the Cremastinae of the Balkan peninsula, Turkey and Cyprus with zoogeographical notes (Hymenoptera: Ichneumonidae). - Beiträge zur Entomologie 47(1): 169-199. 
Kolarov J. 2016: Cremastinae (Hymenoptera, Ichneumonidae) from Turkey and adjacent countries with description of a new species. - Linzer biologische Beiträge 48(2): 1321-1326.

Riedel M. 2017: Die westpaläarktischen Arten der Gattung Campoletis Förster (Hymenoptera, Ichneumonidae, Campopleginae). - Spixiana 40(1): 95-137.

Townes H. 1969: The genera of Ichneumonidae. Part 1. - Memoirs of the American Entomological Institute 11: 1-300.

VAS Z. 2016: A new species of Temelucha Förster from Malta with an updated and revised identification key to the Western Palaearctic Temelucha species (Hymenoptera, Ichneumonidae, Cremastinae). - Journal of Hymenoptera Research 48: 67-84.

https://doi.org/10.3897/JHR.48.7094

VAS Z. 2019a: Contributions to the taxonomy, identification, and biogeography of the Western Palaearctic species of Campoletis Förster (Ichneumonidae: Campopleginae). - Zootaxa 4565(3): 373-382. https://doi.org/10.11646/zootaxa.4565.3.4

VAS Z. 2019b: New species and new records of Campopleginae from the Palaearctic region (Hymenoptera: Ichneumonidae). - Folia entomologica hungarica 80: 247-271.

VAS Z. 2019c: Contributions to the taxonomy, identification, and biogeography of Eriborus Förster, 1869 and Nepiesta Förster, 1869 (Hymenoptera: Ichneumonidae: Campopleginae). Opuscula Zoologica Instituti Zoosystematici et Oecologici Universitatis Budapestinensis 50(1): 87-98. https://doi.org/10.18348/opzool.2019.1.87

VAS Z. 2020: Contributions to the taxonomy and biogeography of Nemeritis Holmgren (Hymenoptera: Ichneumonidae: Campopleginae). - Zootaxa 4758(3): 486-500. https://doi.org/10.11646/zootaxa.4758.3.4

YU D. S. \& Horstmann K. 1997: A catalogue of world Ichneumonidae (Hymenoptera). - The American Entomological Institute, Gainesville, $1558 \mathrm{pp}$.

Yu D. S., van Achterberg C. \& Horstmann K. 2012: Taxapad 2012, Ichneumonoidea 2011. Database on flash-drive. www.taxapad.com, Ottawa, Ontario, Canada. 